\title{
Ana Ürün Koşullarında Yetiştirilen Bazı Yerfıstığı Çeşitlerinin Önemli Agronomik ve Kalite Özelliklerinin Belirlenmesi
}

\author{
Halis ARIOĞLU1 *Halil BAKAL Leyla GÜLLÜOĞLU² Cemal KURT¹ Bihter ONAT³
}

\author{
${ }^{1}$ Çukurova Üniversitesi, Ziraat Fakültesi, Tarla Bitkileri Bölümü, Adana \\ ${ }^{2}$ Çukurova Üniversitesi, Ceyhan MYO, Adana \\ ${ }^{3}$ Çukurova Üniversitesi, Kozan MYO, Adana \\ *Sorumlu yazar e-posta (Corresponding author e-mail): hbakal@cu.edu.tr
}

\section{Öz}

Bu çalışma; ana ürün koşullarında yetiştirilen bazı yerfıstığı çeşitlerinin önemli agronomik ve kalite özelliklerini belirlemek amacıyla yapılmıştır. Araştırmaya konu olan denemeler 2013 ve 2014 yıllarında, Ç.Ü Ziraat Fakültesi, Tarla Bitkileri Bölümüne ait araştırma alanında kurulmuş ve yürütülmüştür. Denemede; Halisbey, Sultan, NC-7, Osmaniye 2005, Batem-5025, Florispan, Brantley, Wilson, Georgia Green, Ha-runner, Flower 22 (Ç-1), Flower 32 (Ç-2) ve Flower 36 (Ç-3) gibi farklı meyve ve tohum özelliğine sahip çeşitler materyal olarak kullanılmıştır. Denemeler tesadüf blokları deneme desenine göre üç tekrarlamalı olarak kurulmuştur. Ekimler Nisan ayının ilk yarısında, hasatlar ise Ekim ayının ilk haftasında yapılmıştır. Denemeye alınan çeşitlere ait; bitki başına meyve sayısı, bitki başına meyve ağırlığı, meyvelerde kalite sınıflaması, 100 meyve ağırığı, 100 tohum ağırlığı, iç oranı, yağ oranı, ham yağ verimi, protein oranı ve dekara verim gibi önemli agronomik ve kalite özellikleri incelenmiştir. İki yıllık sonuçlara göre denemeye alınan yerfıstığı çeşitlerinin kabuklu meyve verimi değerleri 366 -879 kg/da arasında değişim göstermiştir. Dekara en yüksek verim Sultan $(879 \mathrm{~kg} / \mathrm{da})$ ve Halisbey $(779 \mathrm{~kg} / \mathrm{da})$ çeşitlerinden elde edilmiştir. Denemeye alınan yerfıstığı çeşitlerinin yağ oranı \%47-51 arasında, protein oranları ise \%24-28 arasında değişim göstermiştir.

Anahtar Kelimeler: Yerfıstığı, ana ürün, meyve verimi, kalite özellikleri

\section{The Determination of Some Important Agronomical and Quality Properties of Peanut Varieties in Main Crop Conditions}

\begin{abstract}
The objective of this study was to determine important agronomical and quality properties of some peanut varieties in main crop conditions in Cukurova region. 13 peanut varieties such as Halisbey, Sultan, NC-7, Osmaniye 2005, Batem-5025, Florispan, Brantley, Wilson, Georgia green, Ha-runner, Flower-22, Flower-32 and Flower-36 were used as a research material in this study. The experiment was conducted in University farm in 2013 and 2014. The experimental design was a Randomized Complete Block with three replications. The agronomical and quality characteristics such as pod number per plant, pod weight per plant, pod quality calibrations, 100 pod weight, 100 kernel weight, kernel/hull percentage, oil content, crude oil yield, protein content and pod yield per decar were investigated. According to a two-year average, the pod yield was varied between 383-879 kg/da and the highest pod yield was obtained from Sultan ( $879 \mathrm{~kg} / \mathrm{da}$ ) and Halisbey ( 779.2 $\mathrm{kg} / \mathrm{da}$ ) varieties. The oil and protein content of varieties were varied between $47-51 \%$ and $24-28 \%$ respectively.
\end{abstract}

Keywords: Peanut, double crop, pod yield, agronomical characteristics

\section{Giriş}

Y

erfıstığı (Arachis hypogaea L.), kökeni Güney Amerika'ya dayanan, baklagiller familyasından, tek yıllık, yazlık ve yağlı tohumlu bir kültür bitkisidir. İnsan beslenmesinde, hayvan yemi olarak ve toprağa azot bağlaması bakımından çok önemli bir yağ bitkisidir (Arıoğlu 2014).

Yerfıstığı tohumları \%50-55 oranında yağ içermektedir. Yerfıstığı yağı; tat ve dayanıklılık özellikleri bakımından pek çok bitkisel yağdan 
daha üstündür. Bu nedenle çok fazla tüketilmektedir. Özellikle önemli yağ asitlerinden sekiz tanesini içermesi, yağın beslenme değerini arttırmaktadır. Yerfıstığı yağında bol miktarda bulunan Tocofherol, antioksidan bir madde olup, yağın oksitlenme ile bozulmasını önlemektedir. Yağı alındıktan sonra geriye kalan küspe yüksek oranda protein içerdiği için (\%47.4), karma yem üretiminde hammadde olarak kullanılmaktadır. Yerfıstığı küspesinin metabolize enerji değeri $2205 \mathrm{kcal} / \mathrm{kg}$ olup, soya küspesine eşdeğer sayılabilmektedir (Arıoğlu 2014).

Yerfıstığı, 2013 yılında dünya da 25.4 milyon ha alanda yerfıstığı ekimi yapılmış ve 45.2 milyon ton ürün elde edilmiştir. Yerfıstığı, dünyada üretim miktarı bakımından; soya, pamuk ve kolzadan sonra dördüncü sırada yer almaktadır. Dünyada Hindistan, Çin ve Nijerya ekim alanı bakımından ilk sıralarda yer alırken, Sudan, Senegal, Myanmar, Endonezya ve ABD yerfıstığı ekimi yapılan önemli ülkeler arasındadır. Üretimde ise Çin, Hindistan ve Nijerya ilk üç sırayı almaktadır (FAO, 2013).

Türkiye'de 2014 yılında yerfıstığı ekim alanı yaklaşık 333.2 ha olup üretim ise 123.6 bin ton olmuştur.. En çok üretim, Adana ilinde yapılmaktadır ve bunu Osmaniye ilimiz izlemektedir. Ayrıca Aydın, Antalya, Kahramanmaraş, Muğla, Mersin ve Hatay vs. illerimizde üretimi yapılmaktadır (TÜİK 2014).

Çukurova bölgesinde, genellikle (\%95) yatık ve yarı yatık arasında büyüme formuna sahip Virginia grubuna giren NC-7 yerfıstığı çeşidi ekilmektedir. Son yıllarda ise Ç.Ü. Ziraat Fakültesi, Tarla Bitkileri Bölümü tarafından ıslah edilen ve yarı yatık gelişme gösteren Osmaniye-2005, Halisbey ve Sultan gibi çeşitlerin ekimi yaygınlaşmaya başlamıştır. Değişen çevre koşulları nedeniyle, bitkinin büyüme ve gelişmesi farklı olmakta, bu durum verimin değişmesine neden olmaktadır. Bu nedenle, ekim zamanlarına göre uygun yerfıstığı çeşidinin belirlenmesi, birim alandan alınması hedeflenen yüksek verime ulaşmak için önemlidir.

Bölgemizde yerfıstığı tarımı ana ürün ve ikinci ürün olarak iki farklı dönemde yapılmaktadır. Her iki yetişme döneminin de farklı sürelere sahip olması nedeniyle, ekimi yapılacak yerfıstığı çeşitlerinin de uygun yetişme süresine sahip olması gerekmektedir. Birim alanda elde edilecek verimi etkileyen en önemli faktörlerin başında; çeşit seçimi ve uygulanan kültürel yöntemler gelmektedir. Bu nedenle bölgemiz koşullarında yetişebilecek yüksek verimli yerfıstığı çeşitlerini ıslahı veya mevcut çeşitler içerisinde uygun olanların belirlenmesi büyük önem arz etmektedir.

$\mathrm{Bu}$ çalışmanın amacı, farklı büyüme özelliklerine sahip yerfıstığı çeşitlerinin Çukurova bölgesi koşullarında yetişebilme olanaklarını ve verim potansiyellerini belirlemektir. Bu amaca yönelik olarak, farklı meyve ve büyüme özelliğine sahip on üç adet yerfıstığı çeşidi, ana ürün koşullarında yetiştirilmiş ve araştırmada kullanılan çeşitlerin verim potansiyelleri ortaya konmuştur.

\section{Materyal ve Yöntem}

Çukurova Üniversitesi, Ziraat Fakültesi, Tarla Bitkileri Bölümü, Araştırma ve Deneme Alanında, 2013-2014 yılı ana ürün koşullarında iki yıl süreyle yürütülen bu denemede, materyal olarak değişik meyve ve gelişim formu özelliklerine sahip 13 farklı yerfıstığı çeşidi kullanımıştır. Deneme materyali olarak kullanılan yerfıstığı çeşitleri; yarı yatık gelişim formuna sahip Virginia tipi (Halisbey, Sultan, Nc-7, Osmaniye 2005, Batem-5025, Brantley, Wilson, Flower 22 (Ç-1), Flower 32 (Ç-2) ve Flower 36 (Ç-3)), yatık gelişim formuna sahip Runner tipi (Georgia Green, Ha- Runner) ve dik gelişim formuna sahip Spanish (Florispan) olmak üzere üç gruba ayrılmaktadır.

Denemenin kurulduğu topraklar Seyhan nehri yan derelerinin getirdiği çok genç alüviyallerden oluşmuştur. A ve $C$ horizonlarına sahip olup, orta derin ve derin yapılıdır. Organik madde oranı alt katlara gidildikçe azalmaktadır. Denemenin kurulduğu topraklar tınlı yapıda olup, $\mathrm{pH}$ 'sı 7.3 olarak belirlenmiştir. Kullanılabilir $\mathrm{P}_{2} \mathrm{O}_{5}$ miktarı üst katmanlarda \%14.17 seviyesinde olup, bu değer alt katmanlara doğru inildikçe azalmaktadır. Toprağın azot içeriği ise üst katmanlarda $\% 0.122$ iken, alt katmanlarda \%0.056 olarak saptanmıştır. Kireç içeriği ise üst katmanlarda \%33.02 olup, alt katmanlara doğru inildikçe artmaktadır.

Denemenin yürütüldüğü Adana ilinde; kışları ılık ve yağışlı, yazları kurak ve sıcak geçen tipik Akdeniz iklimi hüküm sürmektedir. Deneme süresince aylık ortalama sıcaklık; 2013 yılında $18.1-28.6^{\circ} \mathrm{C}$ arasında, 2014 yılında ise 18.3$29.1^{\circ} \mathrm{C}$ arasında değişim göstermiştir. Denemenin yapıldığı yılda Adana ilinde 
maksimum hava sıcaklığı 2013 yılında Ağustos ayında $35.1^{\circ} \mathrm{C}$ 'ye, 2014 yılında ise $34.5^{\circ} \mathrm{C}^{\prime} \mathrm{ye}$ kadar yükselmiştir. Deneme süresince toplam yağış miktarı 2013 yılında $115.6 \mathrm{~mm}, 2014$ yılında ise $123.7 \mathrm{~mm}$ olmuştur. Ancak, toplam yağışın yetersiz olması nedeniyle gereksinim duyulan su sulamayla karşılanmıştır.

Bu deneme 2013-2014 yılları Nisan-Ekim aylarını kapsayan ana ürün yetiştirme döneminde, Çukurova Üniversitesi Ziraat Fakültesi Tarla Bitkileri Bölümü deneme alanında, tesadüf blokları deneme desenine göre 3 tekrarlamalı olarak kurulmuş ve yürütülmüştür. Her bir deneme parseli $2.8 \mathrm{~m}$ genişliğinde ve $5.0 \mathrm{~m}$ uzunluğunda dört sıradan oluşturulmuş olup, her bir parsel alanı $14.0 \mathrm{~m}^{2}$ olarak düzenlenmiştir. Deneme yeri sonbaharda pullukla derin olarak işlenmiş, kışı bu şekilde geçiren tarla ekimden önce Nisan ayının ilk haftasında kültivatörle yüzlek olarak yeniden işlenmiştir. Ekim öncesi; dekara $20 \mathrm{~kg}$ 18-46 gübresi $(3.6 \mathrm{~kg} / \mathrm{da} \mathrm{N}, 9.2 \mathrm{~kg} / \mathrm{da} \mathrm{P})$ ile yabancı ot ilacı olarak $200 \mathrm{cc} / \mathrm{da}$ herbisit (Traflen) uygulanmıştır. Daha sonra toprak diskaro ile karıştırılmış ve üzerine tapan çekilerek tohum yatağı hazır hale getirilmiştir. Ekim; her iki yılda da Nisan ayını ilk haftasında, markörle belirlenen sıralara 5-6 cm derinliğe gelecek şekilde elle yapılmıştır. Yetişme süresi boyunca gerekli bakım işleri tekniğine uygun olarak zamanında yapılmıştır. Araştırmada; her parselin kenar iki sırası atılarak orta iki sıradaki bitkilerin tamamı elle hasat edilmiştir. Hasat her

Çizelge 1.Yerfıstığı çeşitlerinde 1 kalite meyve sayısı oranı (\%) ve meyve ağırığı oranı değerlerine ait ortalama değerler oluşan gruplar

Table 1. Averages and groups of first class pod number ratios (\%) and pod weight ratios (\%) of peanut varieties

\begin{tabular}{|c|c|c|c|c|c|c|}
\hline \multirow[t]{2}{*}{ ÇEŞIT ADI } & \multicolumn{3}{|c|}{$\begin{array}{l}\text { 1.KALITE MEYVE SAYISI ORANI } \\
(\%)\end{array}$} & \multicolumn{3}{|c|}{$\begin{array}{l}\text { 1.KALITE MEYVE AĞIRLIĞI ORANI } \\
(\%)\end{array}$} \\
\hline & 2013 & 2014 & ORT. & 2013 & 2014 & ORT. \\
\hline HALISBEY & $78.50 \mathrm{bcd}$ & $75.62 \mathrm{~cd}$ & $77.06 \mathrm{~cd}$ & $89.62 \mathrm{abc}$ & $86.84 \mathrm{bc}$ & $88.13 \mathrm{cde}$ \\
\hline SULTAN & $73.39 \mathrm{~cd}$ & $72.99 \mathrm{~cd}$ & $73.19 \mathrm{de}$ & $90.51 \mathrm{abc}$ & $84.51 \mathrm{~cd}$ & $87.50 \mathrm{de}$ \\
\hline OSM-2005 & $79.13 \mathrm{bcd}$ & $72.67 \mathrm{~cd}$ & 75.90 cde & $8.67 \mathrm{abc}$ & $85.32 \mathrm{~cd}$ & $86.84 \mathrm{de}$ \\
\hline NC-7 & $79.30 \mathrm{bcd}$ & $81.87 \mathrm{ab}$ & 80.59 bc & $91.31 \mathrm{abc}$ & $90.26 \mathrm{ab}$ & 90.78 a-d \\
\hline BATEM & $88.81 \mathrm{a}$ & $84.78 \mathrm{a}$ & $86.80 \mathrm{a}$ & $94.07 \mathrm{a}$ & $93.05 \mathrm{a}$ & $93.56 \mathrm{a}$ \\
\hline Ç-1 & $72.70 \mathrm{~cd}$ & $72.82 \mathrm{~cd}$ & $72.76 \mathrm{de}$ & $85.40 \mathrm{bc}$ & $83.81 \mathrm{~cd}$ & 84.60 ef \\
\hline Ç-2 & $71.93 \mathrm{~d}$ & $69.76 \mathrm{~d}$ & $70.84 \mathrm{e}$ & $83.27 \mathrm{c}$ & $81.46 \mathrm{~d}$ & $82.37 \mathrm{f}$ \\
\hline Ç-3 & $71.34 \mathrm{~d}$ & $74.02 \mathrm{~cd}$ & $72.68 \mathrm{de}$ & $84.80 \mathrm{bc}$ & $83.61 \mathrm{~cd}$ & 84,20 ef \\
\hline G.GREEN & $85.37 a b$ & $86.48 \mathrm{a}$ & $85.93 a b$ & $93.67 \mathrm{a}$ & $91.95 \mathrm{a}$ & $92.81 \mathrm{ab}$ \\
\hline HA-RUNNER & $81.69 a b c$ & 77.05 bc & 79.37 c & 90.48 abc & 86.84 bc & $88.65 \mathrm{~b}-\mathrm{e}$ \\
\hline FLORISPAN & $82.90 a b$ & 87.93 a & $85.40 a b$ & $92.58 a b$ & $93.82 \mathrm{a}$ & $93.20 \mathrm{a}$ \\
\hline BRANTLEY & $85.65 a b$ & 85.15 a & $85.42 a b$ & $92.86 a b$ & $91.85 a$ & $92.35 \mathrm{abc}$ \\
\hline WILSON & $76.67 \mathrm{bcd}$ & $76.18 \mathrm{bc}$ & $76.42 \mathrm{~cd}$ & $90.19 a b c$ & $86.01 \mathrm{c}$ & $88.10 \mathrm{cde}$ \\
\hline E.G.F.(\%5) & 9.196 & 6.234 & 5.412 & 8.255 & 4.007 & 4.470 \\
\hline
\end{tabular}

Çizelge 2. Bazı yerfıstığı çeşitlerinde belirlenen 100 meyve ağırlığı ve 100 tohum ağırlığı değerlerine ait ortalama değerler, oluşan gruplar

Table 2. Averages and groups of 100 pod weight and 100 kernel weight of peanut varieties

\begin{tabular}{|c|c|c|c|c|c|c|}
\hline \multirow{2}{*}{ ÇEŞIT ADI } & \multicolumn{3}{|c|}{100 MEYVE AĞIRLIĞI (g) } & \multicolumn{3}{|c|}{100 TOHUM AĞIRLIĞI (g) } \\
\hline & 2013 & 2014 & ORT. & 2013 & 2014 & ORT. \\
\hline HALISBEY & $358.20 \mathrm{ab}$ & $372.02 \mathrm{ab}$ & $365.11 \mathrm{abc}$ & $136.47 \mathrm{a}$ & $136.52 \mathrm{a}$ & $136.49 a b$ \\
\hline SULTAN & $382.44 \mathrm{a}$ & $387.13 \mathrm{a}$ & $384.78 \mathrm{ab}$ & $137.11 \mathrm{a}$ & $136.19 \mathrm{a}$ & $136.64 a b$ \\
\hline OSM-2005 & $396.78 \mathrm{a}$ & $386.20 \mathrm{a}$ & 391.48 a & $136.90 \mathrm{a}$ & $138.67 \mathrm{a}$ & $137.78 \mathrm{a}$ \\
\hline NC-7 & $272.91 \mathrm{bc}$ & $324.29 a b c$ & $298,60 d$ & $104.29 \mathrm{c}$ & $126.52 \mathrm{a}$ & $115.40 \mathrm{~d}$ \\
\hline BATEM & $342.27 \mathrm{ab}$ & $337.06 \mathrm{abc}$ & 339.67 a-d & $126.85 \mathrm{abc}$ & $135.24 \mathrm{a}$ & $131.04 \mathrm{a}-\mathrm{d}$ \\
\hline Ç-1 & $353.36 a b$ & 299.28 c & $326.32 \mathrm{~cd}$ & $128.48 a b$ & $119.20 \mathrm{a}$ & 123.84 a-d \\
\hline Ç-2 & $317.67 \mathrm{ab}$ & $312.79 \mathrm{bc}$ & $315.23 \mathrm{~cd}$ & $112.04 \mathrm{bc}$ & $131.00 \mathrm{a}$ & $121.52 \mathrm{bcd}$ \\
\hline Ç-3 & $365.40 a b$ & $325.25 \mathrm{abc}$ & 345.32 a-d & $128.48 \mathrm{ab}$ & $130.80 \mathrm{a}$ & 129.58 a-d \\
\hline G.GREEN & $138.72 \mathrm{~d}$ & $137.24 d$ & $137.97 \mathrm{f}$ & $66.11 \mathrm{~d}$ & $62.62 \mathrm{bc}$ & $64.36 \mathrm{f}$ \\
\hline HA-RUNNER & $222.72 \mathrm{~cd}$ & $201.53 d$ & $211.86 \mathrm{e}$ & $79.68 \mathrm{~d}$ & $81.13 \mathrm{~b}$ & $80.40 \mathrm{e}$ \\
\hline FLORISPAN & $137.75 \mathrm{~d}$ & $133.84 \mathrm{~d}$ & $135.80 \mathrm{f}$ & $55.80 \mathrm{~d}$ & $57.03 \mathrm{c}$ & $56.41 \mathrm{f}$ \\
\hline BRANTLEY & $321.87 \mathrm{ab}$ & $335.69 \mathrm{abc}$ & $328.78 \mathrm{bcd}$ & $129.51 \mathrm{ab}$ & $133.67 \mathrm{a}$ & $131.59 \mathrm{abc}$ \\
\hline WILSON & $337.59 \mathrm{ab}$ & $324.12 \mathrm{abc}$ & $330.5 \mathrm{bcd}$ & $119.08 \mathrm{bc}$ & $118.82 \mathrm{a}$ & $118.94 \mathrm{~cd}$ \\
\hline E.G.F.(\%5) & 94.279 & 71.344 & 57.590 & 23.906 & 21.967 & 15.814 \\
\hline
\end{tabular}


iki yılda de Ekim ayının ilk haftasında yapılmıştır. Araştırma sonucunda elde edilen veriler JUMP 8.0 istatistiksel paket programı kulanılarak, tesadüf blokları deneme desenine göre varyans analizine tabi tutulmuş ve uygulamalar arasındaki farklılıklar ve oluşan gruplar, EGF (\%5) testine göre belirlenmiştir. Ayrıca, incelenen özellikler arasındaki ilişkileri belirlemek amacıyla korelasyon analizi yapılmıştır.

\section{Bulgular ve Tartışma}

Bu araştırmanın sonuçlarına göre, incelenen özellikler bakımından yerfıstığı çeşitleri arasında önemli farklıkların oluğunu ve incelenen tüm özelliklerin ortalama değerleri ile bu ortalamaların istatistiksel önem düzeyleri aşağıda verilmiştir.
1. Kalite meyve sayısı oranı (1.KMSO) ve 1. Kalite meyve ağılığına (1.KMAO) ait değerler Çizelge 1'de verilmiştir. Çizelge 1 incelendiğinde görüleceği gibi 1. KMSO iki yıllık ortalama değerleri \% 86.60- \%70.72 arasında değişim göstermiştir. En yüksek 1. KMSO (\%86.60) Batem 5025 yerfıstığı çeşidinde elde edilmiştir. 1. KMAO değerleri ise \%93.56 \%82.37 arasında değişim göstermiştir. En yüksek 1. KMAO (\%93.56) Batem 5025 çeşidinden elde edilmiştir. 1. KMSO ile 1. KMAO oranı arasında olumlu ve önemli $(r$ : 0.6972) bir ilişki olduğu saptanmıştır. 13 farkı yerfıstığı çeşidinin Çukurova bölgesinde ana ürün koşullarında yapılan deneme sonucunda 100 meyve ve 100 tohum ağılığı bakımında elde edilen değerler Çizelge 2'de verilmiştir. 2013-2014 yıllarında elde edilen 100 meyve

Çizelge 3. Bazı yerfıstığı çeşitlerinde belirlenen yağ oranı ve yağ verimi değerlerine ait ortalama değerler, oluşan gruplar

Table 3. Averages and groups of oil content and crude oil yield of peanut varieties

\begin{tabular}{|c|c|c|c|c|c|c|}
\hline \multirow{2}{*}{ ÇEŞIT ADI } & \multicolumn{3}{|c|}{ YAĞ ORANI (\%) } & \multicolumn{3}{|c|}{ YAĞ VERİMI (\%) } \\
\hline & 2013 & 2014 & ORT. & 2013 & 2014 & ORT. \\
\hline HALISBEY & 48.30 & 49.58 & 48.94 & 229.1abc & $243.3 \mathrm{~b}$ & $236.3 \mathrm{ab}$ \\
\hline SULTAN & 48.26 & 48.99 & 48.62 & $248.2 \mathrm{ab}$ & $261.8 a b$ & $255.0 \mathrm{a}$ \\
\hline OSM-2005 & 48.88 & 51.68 & 50.28 & $232.5 a b c$ & $270.1 \mathrm{a}$ & $251.3 \mathrm{a}$ \\
\hline NC-7 & 47.74 & 47.37 & 47.55 & $187.3 \mathrm{c}$ & $149.5 \mathrm{fg}$ & $168.4 \mathrm{~d}$ \\
\hline BATEM & 48.14 & 52.14 & 50.14 & $198.0 \mathrm{bc}$ & 181.9cde & $189.9 \mathrm{~cd}$ \\
\hline C-1 & 47.13 & 46.80 & 46.96 & $212.9 b c$ & $193.3 \mathrm{~cd}$ & $203.12 \mathrm{c}$ \\
\hline Ç-2 & 48.52 & 50.00 & 49.26 & 223.2abc & $140.7 \mathrm{~g}$ & $1819 \mathrm{~cd}$ \\
\hline Ç-3 & 50.26 & 51.79 & 51.02 & $243.9 \mathrm{ab}$ & $173.4 \mathrm{c}-\mathrm{f}$ & $208.7 \mathrm{bc}$ \\
\hline G.GREEN & 50.54 & 52.49 & 51.51 & $272.7 \mathrm{a}$ & $253.6 \mathrm{ab}$ & $263.1 \mathrm{a}$ \\
\hline HA-RUNNER & 45.64 & 50.33 & 47.98 & $203.9 b c$ & $199.4 \mathrm{c}$ & $201.6 \mathrm{c}$ \\
\hline FLORISPAN & 46.67 & 50.24 & 48.45 & $95.7 \mathrm{~d}$ & $158.1 \mathrm{efg}$ & $126.9 \mathrm{e}$ \\
\hline BRANTLEY & 47.22 & 50.17 & 48.70 & $217.8 \mathrm{abc}$ & $175.5 \mathrm{c}-\mathrm{f}$ & $196.6 \mathrm{~cd}$ \\
\hline WILSON & 47.93 & 49.15 & 48.54 & $212.4 b c$ & 170.6 def & $191.6 \mathrm{~cd}$ \\
\hline E.G.F.(\%5) & Ö.D. & Ö. D. & Ö. D. & 55.891 & 26.724 & 30.176 \\
\hline
\end{tabular}

Çizelge 4. Bazı yerfıstığı çeşitlerinde belirlenen protein oranı ve iç oranı değerlerine ait ortalama değerler, oluşan gruplar

Table 4. Averages and groups of protein content and kernel/hull percentage of peanut varieties

\begin{tabular}{lllllll}
\hline \multirow{2}{*}{ ÇEŞiT ADI } & \multicolumn{3}{c}{ PROTEIN ORANI (\%) } & \multicolumn{3}{c}{ IÇ ORANI (\%) } \\
\cline { 2 - 7 } & 2013 & 2014 & ORT. & 2013 & 2014 & ORT. \\
\hline HALISBEY & 26.19 & 27.17 & 26.68 & $61.93 \mathrm{ef}$ & $61.97 \mathrm{ef}$ & $61.94 \mathrm{e}$ \\
SULTAN & 26.73 & 27.16 & 26.95 & $58.72 \mathrm{f}$ & $60.46 \mathrm{f}$ & $59.59 \mathrm{e}$ \\
OSM-2005 & 24.94 & 27.44 & 26.19 & $63.84 \mathrm{de}$ & $67.80 \mathrm{~cd}$ & $65.81 \mathrm{~d}$ \\
NC-7 & 25.36 & 29.13 & 27.25 & $70.44 \mathrm{bc}$ & $72.51 \mathrm{a}-\mathrm{d}$ & $71.47 \mathrm{~b}$ \\
BATEM & 27.45 & 27.80 & 27.63 & $67.14 \mathrm{~cd}$ & $73.42 \mathrm{ab}$ & $70.28 \mathrm{bc}$ \\
Ç-1 & 25.87 & 29.27 & 27.57 & $68.09 \mathrm{bcd}$ & $74.19 \mathrm{ab}$ & $71.14 \mathrm{~b}$ \\
Ç-2 & 26.85 & 27.96 & 27.40 & $67.10 \mathrm{~cd}$ & $67.08 \mathrm{~cd}$ & $67.09 \mathrm{~cd}$ \\
Ç-3 & 25.87 & 26.64 & 26.26 & $68.76 \mathrm{bc}$ & $74.92 \mathrm{ab}$ & $71.84 \mathrm{~b}$ \\
G.GREEN & 23.68 & 25.08 & 24.38 & $75.73 \mathrm{a}$ & $77.41 \mathrm{a}$ & $76.56 \mathrm{a}$ \\
HA-RUNNER & 28.70 & 28.67 & 28.69 & $72.57 \mathrm{ab}$ & $70.84 \mathrm{bcd}$ & $71.70 \mathrm{~b}$ \\
FLORISPAN & 26.93 & 28.56 & 27.74 & $67.99 \mathrm{bcd}$ & $72.94 \mathrm{abc}$ & $70.46 \mathrm{bc}$ \\
BRANTLEY & 25.62 & 28.44 & 27.03 & $69.71 \mathrm{bc}$ & $70.64 \mathrm{bcd}$ & $70.17 \mathrm{bc}$ \\
WILSON & 27.06 & 29.05 & 28.06 & $68.11 \mathrm{bcd}$ & $71.22 \mathrm{bcd}$ & $69.66 \mathrm{bc}$ \\
\hline E.G.F.(\%5) & Ö. D. & Ö. D. & Ö. D. & 4.848 & 5.447 & 3.552 \\
\hline
\end{tabular}


ağırlığı değerlerin ortalaması 391.49-135.80 g arasında değişim göstermiştir. En yüksek değer (391.49 g) ise Osmaniye-2005 çeşidinde gözlenmiştir. 100 tohum ağırlığı değerleri 137.78-56.42 g arasındadır. En yüksek 100 tohum ağırlığı (137.78 g) Osmaniye-2005 çeşidi ile elde edilmiştir. 100 tohum ağırlığı ile 100 meyve ağırlığı arasında olumlu ve önemli ( $r$ : 0.8606) bir ilişki olduğu saptanmıştır.

Çukurova bölgesinde ana ürün koşullarında yürütülen çalışma sonucunda elde edilen yağ oranı (\%) ve yağ verimi $(\mathrm{kg} / \mathrm{da})$ verileri Çizelge 3'te verilmiştir. Yağ oranı değerleri \%46.96 ile \%51.51 arasında değişim göstermiştir. En yüksek yağ oranı (\%51.51) Georgia Green çeşidinde gözlenmiştir. Çeşitler arasındaki yağ oranlarının istatistiksel olarak önemsiz olduğu belirlenmiştir. Yağ verimi, yağ oranı ve dekara meyve verimi ile olumlu ve önemli (r: 0.8563) düzeyde ilişkilidir. En yüksek yağ verimi 263.27 kg/da ile Georgia Green çeşidinden elde edilmiştir.

Çukurova bölgesinde ana ürün koşullarında yetiştirilen 13 farklı yerfıstığı çeşitlerinden elde edilen Protein oranı ve iç oranı değerleri Çizelge 4'te verilmiştir. Protein oranı değerleri istatistiksel olarak önemli çıkmamıştır. En yüksek protein oranı değeri ise Ha- Runner (\%28.69) çeşidinde gözlenmiştir. İç oranı değerleri ise her iki yılda da istatistiksel olarak önemli çıkmıştır. En yüksek iç oranı G.Green (\% 76.57) adlı çeşitte belirlenmiştir.

Çizelge 5 .Bazı yerfıstığı çeşitlerinde belirlenen bitki başına meyve sayısı ve bitki başına meyve ağırlığı değerlerine ait ortalama değerler, oluşan gruplar

Table 5. Averages and groups of pod number per plant and pod weight per plant of peanut varieties

\begin{tabular}{|c|c|c|c|c|c|c|}
\hline \multirow{2}{*}{ ÇEŞIT ADI } & \multicolumn{3}{|c|}{ BITKI BAŞINA MEYVE SAYISI } & \multicolumn{3}{|c|}{ BITKKI BAŞINA MEYVE AĞIRLIĞI } \\
\hline & 2013 & 2014 & ORT. & 2013 & 2014 & ORT. \\
\hline HALISBEY & $25.36 \mathrm{~cd}$ & 29.47 def & $27.41 \mathrm{de}$ & $89.29 \mathrm{~b}$ & $84.60 \mathrm{a}$ & $86.94 \mathrm{~b}$ \\
\hline SULTAN & $33.89 \mathrm{bc}$ & $33.63 \mathrm{~cd}$ & $33.76 \mathrm{bc}$ & $105.86 \mathrm{a}$ & $85.25 \mathrm{a}$ & $95.55 \mathrm{a}$ \\
\hline OSM-2005 & $25.61 \mathrm{~cd}$ & 28.15 def & 26.89 def & 87.77 b & 79.93 a & $83.85 \mathrm{bc}$ \\
\hline NC-7 & $19.63 \mathrm{~d}$ & $22.40 \mathrm{fg}$ & $21.01 \mathrm{f}$ & $65.78 \mathrm{~d}$ & 52.95 de & $59.36 \mathrm{~g}$ \\
\hline BATEM & $28.14 \mathrm{~cd}$ & $19.50 \mathrm{~g}$ & 23.82 ef & $81.30 \mathrm{bc}$ & $50.62 \mathrm{e}$ & 65.96 efg \\
\hline Ç-1 & $30.32 \mathrm{bc}$ & 30.52 cde & $30.42 \mathrm{~cd}$ & $77.51 \mathrm{bcd}$ & $70.02 \mathrm{~b}$ & $73.76 \mathrm{~d}$ \\
\hline Ç-2 & $32.16 \mathrm{bc}$ & 28.05 def & $30.11 \mathrm{~cd}$ & $78.53 \mathrm{bc}$ & $60.87 \mathrm{bcd}$ & 69.69 def \\
\hline Ç-3 & $32.93 \mathrm{bc}$ & $25.40 \mathrm{efg}$ & 29.17 cde & $81.79 b$ & $63.05 \mathrm{bc}$ & $72.42 \mathrm{de}$ \\
\hline G.GREEN & $50.05 a$ & $54.73 \mathrm{a}$ & 52.39 a & 86.87 b & $67.30 \mathrm{~b}$ & $77.08 \mathrm{~cd}$ \\
\hline HA-RUNNER & 38.02 b & $37.90 \mathrm{bc}$ & $37.96 \mathrm{~b}$ & $69.31 \mathrm{~cd}$ & 56.50 cde & $62.90 \mathrm{fg}$ \\
\hline FLORISPAN & $28.93 \mathrm{bc}$ & $44.40 \mathrm{~b}$ & $36.67 \mathrm{~b}$ & $35.47 \mathrm{e}$ & 55.53 cde & $45.50 h$ \\
\hline BRANTLEY & $27.97 \mathrm{~cd}$ & 24.30 efg & 26.14 def & $80.60 \mathrm{bc}$ & 66.87 b & $73.73 d$ \\
\hline WILSON & $31.12 \mathrm{bc}$ & 29.60 def & $30.36 \mathrm{~cd}$ & $82.02 \mathrm{~b}$ & $69.63 \mathrm{~b}$ & $75.83 \mathrm{~d}$ \\
\hline E.G.F.(\%5) & 9.236 & 7.725 & 5.865 & 12.169 & 9.473 & 7.512 \\
\hline
\end{tabular}

Çizelge 6. Bazı yerfıstığı çeşitlerinde belirlenen verim değerlerine ait ortalamalar ve oluşan gruplar Table 6. Averages and groups of pod yield per decar of peanut varieties

\begin{tabular}{llll}
\hline & \multicolumn{3}{c}{ DEKARA MEYVE VERIMi $(\mathrm{kg} / \mathrm{da})$} \\
\cline { 2 - 4 } ÇEŞiT ADI & \multicolumn{1}{c}{2013} & \multicolumn{1}{c}{2014} & ORT. \\
\cline { 2 - 4 } HALISBEY & $766.2 \mathrm{ab}$ & $792.2 \mathrm{ab}$ & $779.2 \mathrm{~b}$ \\
SULTAN & $875.3 \mathrm{a}$ & $884.0 \mathrm{a}$ & $879.6 \mathrm{a}$ \\
OSM-2005 & $745.4 \mathrm{abc}$ & $770.3 \mathrm{~b}$ & $757.8 \mathrm{~b}$ \\
NC-7 & $557.0 \mathrm{~d}$ & $435.1 \mathrm{e}$ & $496.0 \mathrm{e}$ \\
BATEM & $611.9 \mathrm{~cd}$ & $475.6 \mathrm{de}$ & $543.7 \mathrm{de}$ \\
Ç-1 & $663.7 \mathrm{bcd}$ & $556.8 \mathrm{~cd}$ & $610.3 \mathrm{~cd}$ \\
Ç-2 & $684.4 \mathrm{bcd}$ & $399.1 \mathrm{e}$ & $541.8 \mathrm{de}$ \\
Ç-3 & $707.1 \mathrm{bc}$ & $446.9 \mathrm{e}$ & $577.0 \mathrm{de}$ \\
G.GREEN & $712.3 \mathrm{bc}$ & $624.2 \mathrm{c}$ & $668.2 \mathrm{c}$ \\
HA-RUNNER & $616.4 \mathrm{~cd}$ & $559.5 \mathrm{~cd}$ & $588.0 \mathrm{~cd}$ \\
FLORISPAN & $301.7 \mathrm{e}$ & $431.5 \mathrm{e}$ & $366.6 \mathrm{f}$ \\
BRANTLEY & $659.6 \mathrm{bcd}$ & $495.3 \mathrm{de}$ & $577.5 \mathrm{de}$ \\
WiLSON & $651.0 \mathrm{bcd}$ & $487.5 \mathrm{de}$ & $569.2 \mathrm{de}$ \\
\hline E.G.F.(\%5) & 139.344 & 108.250 & 85.948 \\
\hline
\end{tabular}


Bitki başına meyve sayısı ve bitki başına meyve ağırlığı değerleri Çizelge 5 'te verilmiştir. Çizelge 6 incelendiğinde bitki başına meyve sayısı 21.03-52.39 adet meyve arasında değişmektedir. En yüksek bitki başına meyve sayısı Georgia Green çeşidinden elde edilmiştir. Bitki başına meyve ağırlığı değerleri incelendiğinde $\quad 45.50-95.55 \mathrm{~g}$ arasında değişmektedir. En yüksek bitki başına meyve ağırlığı $95.55 \mathrm{~g}$ ile Sultan çeşidindedir.

13 farklı yerfıstığı çeşidi ile yürütülen bu çalışmanın sonuçlarına göre, her iki yılda da Sultan çeşidinden en yüksek $(879.6 \mathrm{~kg} / \mathrm{da})$ dekara meyve verimi alınmıştır. Ana ürün koşullarında yürütülen bu çalışmada dekara meyve verimi değerleri 366.6-879.6 kg/da arasında değişim göstermiş̧ir. Dekara meyve verimi, bitki başına meyve sayısı ( $r$ : 0.5488) ve iç oranı (r: 0.6009) ile olumlu ve önemli bir ilişkisi olduğu belirlenmiştir.

\section{Sonuç}

Yerfıstığı üretiminin yaklaşık \%95'nin gerçekleştiği Çukurova bölgesinde, ana ürün ve ikinci ürün olarak yapılmaktadır. Bölgemizde yaygın olarak (\%95), yatık - yarı yatık arası büyüme formuna sahip Virginia grubuna giren NC-7 yerfıstığı çeşidi ekilmektedir. Yatık gelişim formuna sahip Runner grubu ve dik gelişme formuna sahip Spanish ve Valencia grubuna giren yerfıstığı çeşitlerinin ise, ülkemizde henüz ekim yapılmamaktadır. Yapılan bu çalışma ile G.Green çeşidinden elde edilen verilen incelendiğinde de görüleceği gibi dekara verim değeri standart çeşitten (NC-7) \%28.55 daha fazladır. Yağ oranı bakımından ise on üç arasında en yüksek yağ oranına (\%51.51) sahip olan çeşittir. Deneme bulguları göz önüne alındığında Runner tipi G.Green ve Ha-Runner yerfıstığı çeşitlerinin Çukurova Bölgesinde ana ürün koşullarında başarıyla yetiştirebileceği ortaya konmuştur.

Ayrıca, Ç.Ü. Ziraat Fakültesi tarafında tescil ettiren Halisbey, Sultan ve Osmaniye-2005 çeşitleri standart çeşide göre oldukça yüksek verim elde edilmiştir. Çukurova bölgesinde standart olarak yetiştirilen NC-7 çeşidine göre Sultan çeşidi \%57.14 ve Halisbey çeşidi \%37.55 daha yüksek dekara verim verdiği belirlenmiştir.

\section{Kaynaklar}

Arıoğlu H.H., 2014. Yağ Bitkileri Yetiştirme ve Islahı. Çukurova Üniversitesi, Ziraat fakültesi Ders Kitabı No:220, A-70, Adana

Arıoğlu H.H., İşler N., 1990a. Çukurova Bölgesinde ana ürün olarak yetiştirilecek bazı Runner ve Virginia tipi yerfıstığı (Arachis hypogaea L.) çeşitleri üzerine bir araştırma. Ç.Ü.Z.F. Dergisi 5(3): 121-136

Arıoğlu H.H., İşler N., 1990a. Çukurova bölgesinde ana ürün olarak yetiştirilecek bazı Spanih ve Valencia tipi yerfıstığı (Arachis hypogaea L.) çeşitleri üzerine bir araştırma. Ç.Ü.Z.F. Dergisi, 5(4): 95-110

Çalışkan M.E., Mert M., İşler N., Çalışkan S., 2000. Hatay yöresinde II. ürün olarak yetiştirilen Virginia tipi bazı yerfıstığı (Arachis hypogaea L. subs. hypogaea var. hypogaea) genotiplerinin önemli tarımsal ve kalite özellikleri ile bu özelliklerin verim oluşumuna etkileri. Turk J Agric For., 24: 87-94

FAO 2013. İstatistik Bölümü İnternet Sitesi. http://faostat.fao.org

İşler N., Çalışkan M.E., Boydak E., 1997. Virginia Tipi Bazı Yerfıstığı (Arachis hypogaea L.) Çeşitlerinin Şanlıurfa Bölgesi Ana Ürün Koşullarındaki Verimi ile Bitkisel Özelliklerinin Belirlenmesi. Türkiye II. Tarla Bitkileri Kongresi, 22-25 Eylül 1997, Samsun, s:631633

TÜIK 2014. Türkiye İstatistik Kurumu İnternet Sitesi. http://tuikapp.tuik.gov.tr/bitkiselapp/bitkilel.zul 